\title{
Dampak Relokasi Pasar Tradisional terhadap Kondisis Sosial Ekonomi Pedagang di Pasar Kertosono Kabupaten Nganjuk
}

\author{
Ermita Yusida $^{1)}$, Frada Nadya Megatara Putra ${ }^{2{ }^{*}}$, Hadi Sumarsono ${ }^{3)}$ \\ 1) 2) Universitas Negeri Malang, Indonesia \\ *E-mail corresponding author: ermita.yusida.fe@um.ac.id
}

Received: 28-02-2021;

Accepted: 18-03-2021;

Available online: 30-04-2021

Ecoplan Vol. 4 No. 1, April 2021, hlm 54-66.

\section{ISSN p: 2620-6102 \\ e: 2615-5575}

Abstract - This study aims to determine traders' responses regarding the relocation policy of Kertosono Market, accessibility to the Kertosono Market before and after relocation, the impact of the relocation of Kertosono Market social-economic conditions of traders. This research is quantitative descriptive. The population in this study were all traders who sell at Kertosono Market. The results showed that $83.07 \%$ of respondents did not agree with the relocation. Accessibility to Kertosono Market before and after relocation was 63.07\% of the respondents' residences were $>1 \mathrm{~km}$ away before relocation, $55.38 \%$ were $>1 \mathrm{~km}$ out after relocation. The impact of relocating Kertosono Market on the social-economic conditions was $92.30 \%$ of respondents were comfortable selling, $7.69 \%$ encountered problems, $96.92 \%$ were able to advance, and after relocation, namely $84.61 \%$ of respondents were uncomfortable when selling, $15.38 \%$ found no issues, $92.30 \%$ were unable to progress. After relocation, the economic condition of traders increased by $81.53 \%$ in the very low classification, decreasing $33.84 \%$ in the high category. Therefore, capital assistance for small traders is very much needed. So, in addition to providing capital assistance, the government should also offer training in the form of financial planning and digital marketing so that traders can expand their business. In the future, there needs to be a particular study regarding the comparison of traders in traditional markets and modern markets.

\begin{abstract}
Abstrak - Penelitian ini bertujuan untuk mengetahui tanggapan pedagang menyikapi kebijakan relokasi Pasar Kertosono, aksesibilitas menuju Pasar Kertosono sebelum dan sesudah relokasi, dampak relokasi Pasar Kertosono terhadap kondisi ekonomi sosial pedagang. Penelitian ini merupakan penelitian deskriptif kuantitatif. Populasi dalam penelitian ini adalah seluruh pedagang yang berjualan di Pasar Kertosono. Hasil penelitian menunjukkan bahwa 83,07\% responden tidak setuju dengan adanya relokasi. Aksesibilitas menuju Pasar Kertosono sebelum dan sesudah relokasi yaitu 63,07\% tempat tinggal responden berjarak $>1$ $\mathrm{Km}$ sebelum relokasi, 55,38\% berjarak $>1 \mathrm{Km}$ setelah relokasi. Dampak relokasi Pasar Kertosono terhadap kondisi ekonomi sosial pedagang sebelum relokasi yaitu $92,30 \%$ responden nyaman saat berjualan, 7,69\% menjumpai permasalahan, $96,92 \%$ dapat maju, dan sesudah relokasi yaitu $84,61 \%$ responden tidak nyaman saat berjualan, 15,38\% tidak menjumpai permasalahan, 92,30\% tidak dapat maju. Kondisi ekonomi pedagang sesudah relokasi meningkat $81,53 \%$ pada klasifikasi sangat rendah, menurun $33,84 \%$ pada klasifikasi tinggi. Bantuan modal bagi pedagang kecil ini sangat dibutuhkan. Sehingga, selain bantuan modal, pemerintah juga harus memberikan edukasi mengenai perencanaan keuangan dan digital marketing agar pedagang dapat melakukan ekspansi usahanya. Kedepan, perlu adanya telaah lebih lanjut mengenai perbedaan pedagang pasar tradisional dan pasar modern baik dari sisi ekonomi maupun sosialnya.
\end{abstract}

Kata Kunci: pedagang Pasar Kertosono, relokasi pasar, dampak sosial ekonomi. 


\section{PENDAHULUAN}

Seiring perkembangan jaman dan semakin meningkatnya kebutuhan masyarakat di segala sektor kehidupan, maka masyarakat dituntut untuk dapat mempunyai penghasilan yang lebih untuk memenuhi segala macam kebutuhannya. Oleh karena itu, masyarakat tidak hanya mengandalkan satu mata pencaharian. Bahkan dewasa ini masyarakat mulai berani meninggalkan mata pencaharian yang dinilai kurang untuk mencukupi kebutuhan hidup, yaitu mata pencaharian di sektor pertanian. Susilowati (2014) menemukan bahwa dari tahun 2013 hingga 2017 jumlah tenaga kerja di sektor pertanian semakin berkurang.

Sektor pertanian mulai ditinggalkan sebagai mata pencaharian utama masyarakat salah satu dipengaruhi oleh faktor pendapatan dan tingkat upah tenaga kerja pertanian yang rendah disertai dengan pandangan bahwa pertanian tidak menjamin kontinuitas dan stabilitas pendapatan serta beresiko tinggi (Susilowati, 2016). Sebagian masyarakat memilih berdagang untuk meningkatkan pendapatannya. Berdasarkan hasil observasi awal yang dilakukan peneliti, banyak masyarakat yang beralih menjadi pedagang karena dinilai keuntungan yang diperoleh dari berdagang mampu untuk mencukupi kebutuhannya selama masih banyaknya minat pembeli dan adanya tempat untuk berdagang salah satunya yaitu pasar tradisional.

Pasar tradisional yakni pasar yang dikelola sekaligus dibangun oleh BUMD, BUMN, pemerintah, maupun pihak swasta (Perpres RI No. 112 Tahun 2007). Bentuk kerjasama yang dilakukan dengan pihak swasta dapat berupa kerjasama tempat usaha yang dioperasikan oleh pedagang, koperasi, maupun swadaya masyarakat, di mana proses jual beli dilakukan dengan tawar menawar. Pendirian pasar tradisional harus memenuhi persyaratan yakni setiap $100 \mathrm{~m}^{2}$ harus menyiapkan tempat parkir minimal untuk satu unit kendaraan beroda empat, luas lapak dagang memperhitungkan kondisi ekonomi dan sosial masyarakat, serta menjamin pasar tradisional tetap tertib, aman, bersih, higienis, sehat, dan menyediakan ruang publik yang nyaman.

Seiring dengan perkembangan jaman dan perkembangan teknologi, berdirinya pusat perbelanjaan modern mendesak keberadaan pasar tradisional (Pramudyo, 2014). Pusat perbelanjaan modern mewarkan pelayanan yang lebih baik dan nyaman sehingga masyarakat akan memilih untuk berbelanja di supermarket, minimarket, dan hypermarket (Nurjanah, 2020). Semakin banyaknya pasar modern menyebabkan pasar tradisional mulai dilupakan dan diabaikan. Adanya sebagian masyarakat yang menganggap bahwa pasar tradisional itu tidak nyaman, kotor, dan barang yang ditawarkan tidak berkualitas menyebabkan pasar tradisional semakin tertinggal. Anggapan tersebut sesuai dengan kondisi fisik pasar tradisional yang tua tanpa renovasi yang menyebabkan pasar tradisional semakin kalah saing dengan ritel modern (Muslimin, Indriati and Widayanti, 2018). Bahkan, pasar tradisional dianggap sebagai slum area yang mengakibatkan pembeli beralih ke pasar modern (Masitoh, 2013).

Apabila diamati lebih lanjut, pasar tradisional memiliki kelebihan secara sosial dibandingkan dengan pasar modern. Misalnya, kegiatan tawar menawar yang sebenarnya dapat menciptakan kontak sosial tersendiri antara pedagang dan pembeli yang tidak akan ditemui di pasar modern (Yudha, 2017). Barang yang ditawarkan penjual memiliki kualitas setara bahkan sama dengan barang yang dijual di pasar modern. Contohnya, buah dan sayur yang masih segar, sembilan bahan pangan pokok yang berkualitas, serta pakaian yang memiliki kualitas dan harga beragam, dari yang mahal sampai yang harganya murah, sehingga konsumen dapat menyesuaikan dengan budget yang dimiliki. Berbanding terbalik dengan pasar modern di mana tidak ada kegiatan tawar- menawar dikarenakan harga sudah ditentukan.

Pasar tradisional memiliki peran penting dalam pemenuhan kebutuhan masyarakat, dan menyediakan lapangan kerja untuk warga dengan kondisi ekonomi menengah ke bawah (Ars, 2015). Pasar tradisional juga berfungsi untuk meningkatkan pendapatan. Di pasar tradisional juga terbentuk komunitas yang anggotanya berasal dari berbagai unsur, mulai dari pedagang, kuli angkut, tukang becak, pedagang kaki lima, pembeli, hingga para supplier. Oleh sebab itu, pasar tradisional harus dipertahankan eksistensinya sebagai sarana interaksi sosial budaya dan sarana konsepsi hidup (Aliyah, Setioko and Wisnu, 2015).

Sampai saat ini pasar tradisional Kertonoso atau disebut Pasar Kertosono menjadi pusat kegiatan sosial ekonomi bagi masyarakat Kertosono karena Pemerintah Daerah Kabupaten Nganjuk telah berkomitmen untuk menjaga eksistensi pasar tradisional. Tujuannya, agar pasar tradisional tetap terjaga keberadaannya karena merupakan sektor utama perekonomian masyarakat Kertosono dan merupakan salah satu aset daerah. Pasar Kertosono masih bertahan di tengah maraknya pasar modern yang sudah berkembang pada saat ini. Pasar Kertosono masih menjadi tumpuan warga masyarakat Kecamatan Kertosono terutama di Kelurahan Banaran dan sekitarnya sebagai sumber pendapatan sehari-hari untuk 
memenuhi kebutuhan sehari-hari. Dengan demikian, perlu dilakukannya relokasi ke tempat lain karena musibah yang menimpa Pasar Kertosono lama yaitu kebakaran atau bencana alam yang dialami seluruh pedagang Pasar Kertosono mengakibatkan kerugian besar-besaran bagi seluruh pedagang. Berdasaran hasil observasi yang telah dilakukan, lokasi Pasar Kertosono baru menempati bekas tempat imigrasi dan halaman Balai Kelurahan di Jalan Ronggo Warsito.

Kondisi Pasar Kertosono Baru setelah relokasi sangat berbeda dengan kondisi di Pasar Kertosono Lama. Setelah relokasi pasar ini diberlakukan adanya persamaan rata lapak (bedak toko) yang sebelumnya pada pasar lama pedagang ada yang mempunyai lapak berukuran lebih besar daripada pedagang yang lain. Lalu adanya sistem zonasi yang berfungsi untuk penataan pedagang. Akan tetapi dengan adanya sistem zonasi masih belum optimal dan masih berantakan, mengingat pembeli yang mempunyai pedagang langganan akan sulit untuk mencari atau mengingat pedagang A berdekatan dengan pedagang B. Maksud diadakannya sistem zonasi yang diberlakukan oleh Pemerintah Daerah adalah untuk memberikan pelayanan yang maksimal kepada konsumen serta memudahkan pembeli dalam mendapatkan barang. Tentu saja dengan adanya sistem zonasi membuat persaingan pedagang meruncing karena pedagang yang menjual barang dagangan sejenis berada dalam satu lokasi yang sama, sehingga persaingan untuk mendapatkan pelanggan juga semakin kuat.

Hal ini tentunya dapat berpengaruh pada kondisi ekonomi pedagang dimana dengan lokasi berdagang yang berbeda dan juga kondisi pasar yang berbeda dapat berpengaruh pada pendapatan pedagang. Pasca relokasi kondisi sosial pedagang tentu juga akan mengalami perubahan terutama dari segi Paguyuban yang terbentuk oleh pedagang di Pasar Kertosono lama ini tentunya akan mempengaruhi kondisi sosial pedagang setelah relokasi pasar terjadi. Kebaruan dari penelitian ini yaitu tidak hanya melihat dari kondisi ekonomi saja tetapi juga melihat dari persepsi masyarakat dengan lokasi pasar yang baru dalam kemajuan usahanya kedepan.

Berdasarkan pemaparan masalah di atas, peneliti bermaksud untuk mengetahui secara mendalam terkait kondisi sosial ekonomi pedagang terdampak relokasi pasar. Peneliti tergerak untuk melakukan riset yang berjudul "Dampak Relokasi Pasar terhadap Kondisi Sosial Ekonomi Pedagang di Pasar Kertosono Kabupaten Nganjuk". Tujuan umum riset ini adalah untuk mengetahui dampak relokasi Pasar Kertosono terhadap kondisi ekonomi dan kondisi sosial pedagang, serta sebagai evaluasi jalannya instansi dengan kesesuaian teori dan keadaan ideal yang diharapkan.

\section{TINJAUAN PUSTAKA \\ Relokasi}

Tarigan (2006) menyebutkan teori lokasi sebagai suatu ilmu yang menelusuri tentang alokasi geografis dari berbagai sumber yang berpotensi, serta kaitannya dengan keberadaan bermacam-macam aktivitas. Selain itu, Sari (2006) menyebutkan relokasi dalam Kamus Besar Bahasa Indonesia diartikan dengan mengonstruksi kembali prasarana umum, perumahan, meliputi tanah produktif di tempat lainnya. Perencanaan dan pembangunan relokasi akan berdampak pada stakeholder di dalamnya. Lokasi pada berbagai aktivitas seperti pertokoan, rumah tangga, pertanian, sekolah, rumah sakit, hingga tempat ibadah menunjukkan susunan dan pola yang dapat dipejari dan dipahami.

Tempat relokasi dan lokasi yang baru merupakan faktor utama dalam perencanaan relokasi, sebab lokasi sangat menentukan tingkat aksesibilitas ke tempat usaha, pekerjaan lapangan usaha, jaringan sosial, dan peluang pasar (Musthofa, 2011). Masing-masing tempat memiliki peluang dan keterbatasan tersendiri. Pemilihan lokasi yang memiliki karakteristik sama baik dengan kawasan yang sebelumnya akan meningkatkan kemungkinan berhasilnya relokasi dan pemulihan pendapatan pedagang. Musthofa (2011) menyatakan bahwa untuk mempertahankan ikatan masyarakat dan jaringan sosial yang terjalin dengan baik sebelumnya maka sebaiknya tempat relokasi baru dekat dengan tempat lama.

Di bawah ini adalah persyaratan yang harus dilengkapi untuk mencapai keseimbangan ekonomi ruang (Losch, 1954):

1) Pembeli memiliki sikap indifferent terhadap penjual mana pun dan harga yang rendah merupakan satu satunya pertimbangan untuk membeli barang tersebut.

2) Masing-masing tempat usaha menjamin keuntungan maksimal bagi pembeli maupun penjual.

3) Banyak usaha pertanian yang menyebar secara merata sehingga seluruh permintaan konsumen dapat dipenuhi.

\section{Pasar}

Menurut Wicaksono dalam Hasnawati (2016) pasar adalah interaksi antara pembeli dan penjual yang melayani transaksi jual beli. Pasar sebagai area perdagangan barang maupun jasa dengan lebih dari satu penjual, baik dalam bentuk pasar tradisional, pusat perdagangan, pusat perbelanjaan, plaza, mall, dan lain sebagainya (Permendagri No. 70/M- DAG/PER/12/2013) 
Masyarakat secara umum mengetahui dua jenis pasar yaitu pasar modern dan pasar tradisional. Keduanya memiliki karakteristik yang berbeda apabila dipandang dari sudut pandang tempat berdagang, bangunan, dan sistem jual beli yang ada. Pada umumnya, pasar tradisional terdiri deretan tenda yang bersifat non-permanen, dan lingkungan yang kotor, bau, becek sehingga pembeli merasa tidak nyaman dan tidak aman. Menurut Izza (2010), pasar modern umumnya mempunyai fasilitas memadai, bangunan megah dan permanen, banyaknya diskon yang ditawarkan, aman, nyaman, dan harga yang tercantum adalah tetap, tidak bisa ditawar. Wiryomartono (1995) mendefinisikan pasar tradisional sebagai tempat terjadinya peristiwa interaksi ekonomi dan interaksi sosial yang berkembang secara periodik. Kata pasar berasal dari Bahsa Jawa yaitu 'peken' yang artinya kumpul.

Widodo (2008) mendefinisikan pasar modern sebagai pasar yang didirikan oleh pihak swasta, pemerintah, atau koperasi, seperti Supermarket, Mall, dan pusat perbelanjaan yang dikelola secara modern dan memprioritaskan rasa nyaman bagi konsumen dalam berbelanja, pengelolaan dipegang oleh satu tangan, dilengkapi dengan harga yang pasti, dan modal usaha yang relatif besar. Muta'ali (2015) mengemukakan bahwa pasar modern tidak memiliki perbedaan yang signifikan dengan pasar tradisional. Perbedaannya, di pasar modern, konsumen dan pedagang tidak melakukan transaksi secara langsung. Konsumen cukup melihat label harga yang tertera, pelayanan dilakukan dilakukan oleh pramuniaga maupun secara mandiri, dan berada di dalam bangunan besar.

\section{Kondisi Sosial Ekonomi}

Kemudian, masyarakat dikelompokkan menurut kondisi sosial ekonomi menjadi kelompok bawah, menengah, dan atas berdasarkan tingkat pendapatan dan lingkungannya (Koentjaraningrat, 1981). Kondisi sosial ekonomi diartikan sebagai berbagai hal yang berhubungan dengan kesejahteraan masyarakat, khususnya dalam pemenuhan kebutuhan. Kondisi sosial dan ekonomu masyarakat dapat dilihat dari tingkat pendidikan, tingkat pemenuhan kebutuhan sehari-hari, pekerjaan, dan kesehatan (Melly G.Tan dalam Hasnawati, 2016). Notoadmodjo dalam Hasnawati (2016) berpendapat bahwa kondisi ekonomi dan sosial sebagai suatu konsep, yang dapat diukur melalui variablel tingkat pendidikan, variabel pendapatan keluarga, dan variablel pekerajaan. Hasnawati (2016) juga mengemukakan bahwa sosial ekonomi merupakan gambaran keadaan suatu masyarakat atau individu yang dilihat dari sudut pandang ekonomi dan sosial, seperti tingkat pendidikan, kesehatan, pendapatan dan indikator lainnya.

Kondisi sosial ekonomi mencerminkan kedudukan seseorang menempatkannya pada posisi tertentu di masyarakat yang diatur secara sosial. Pemberian posisi tersebut diikuti dengan kewajiban dan hak yang harus dilaksanakan oleh penerima status sosial ekonomi tersebut (Hasnawati, 2016).

\section{Konsep Pedagang}

Secara umum, pedagang dikenal sebagai badan atau individu yang menjual barang atau jasa kepada konsumen. Studi sosiologi ekonomi yang dilaksanakan oleh Mai dan Bucholt dalam Hasnawati (2016) tentang pedagang menemukan bahwa pedagang diklasifikasikan menjadi:

1) Pedagang semu: orang yang berdagang hanya untuk mendapatkan melakukan hobinya dan mengisi waktu luang. Ia tidak menjadikan kegiatan dagang sebagai sumber keuntungan, sehingga mungkin saja ia justru mengalami kerugian.

2) Pedagang semiprofessional: orang yang berdagang dan melakukan kegiatannya untuk mendapatkan uang, tetapi keuntungan dari hasil perdagangan tersebut bukanlah sumber pendapatan utama, melainkan sebagai sumber pendapatan tambahan.

3) Pedagang professional: orang yang berdagang dan menganggap kegiatan berdagangnya sebagai sumber penghasilan utama bagi ekonomi keluarga.

Berdasarkan pemaparan di atas, dapat disimpulkan bahwa pedagang yaitu orang yang berusaha untuk menjual barang dan jasa yang dibutuhkan masyarakat dan membuat barang/jasa yang ditawarkannya semenarik mungkin untuk menarik konsumen.

\section{METODE PENELITIAN}

Riset ini adalah berjenis deskriptif kuantitatif berdasarkan angket yang telah disebarkan dengan jenis pertanyaan tertutup. Peneliti menetapkan populasi dalam riset ini yaitu semua pedagang yang berdagang di Pasar Kertosono dengan jumlah 654 orang, dan sampel sebanyak 65 orang yaitu 10 persen dari populasi dengan pertimbangan jumlah populasi yang relative kecil. pedagang dengan teknik simple random sampling. Perhitungan sampel ini berdasarkan pada Pengumpulan data dilakukan melalui teknik dokumentasi, wawancara, dan observasi. Data hasil penelitian diolah melalui tahapan editing dan tabulasi. Data yang digunakan dalam penelitian ini yaitu tahun 2019. 


\section{HASIL DAN PEMBAHASAN}

Riset yang dilakukan di Pasar Kertosono, diperoleh data sebagai berikut:

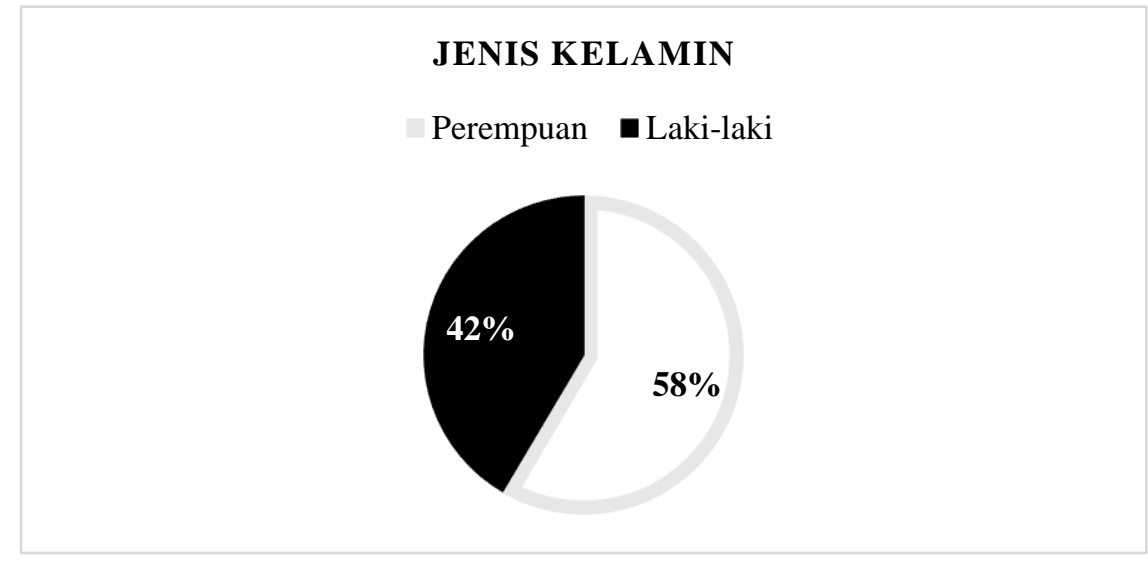

Gambar 1. Jenis Kelamin Pedagang di Pasar Kertosono

Sumber: Dokumen peneliti

Berdasarkan data pada Gambar 1, diketahui bahwa mayoritas pedagang yang direlokasi di Pasar Kertosono berjenis kelamin perempuan dengan persentase mencapai $58 \%$.

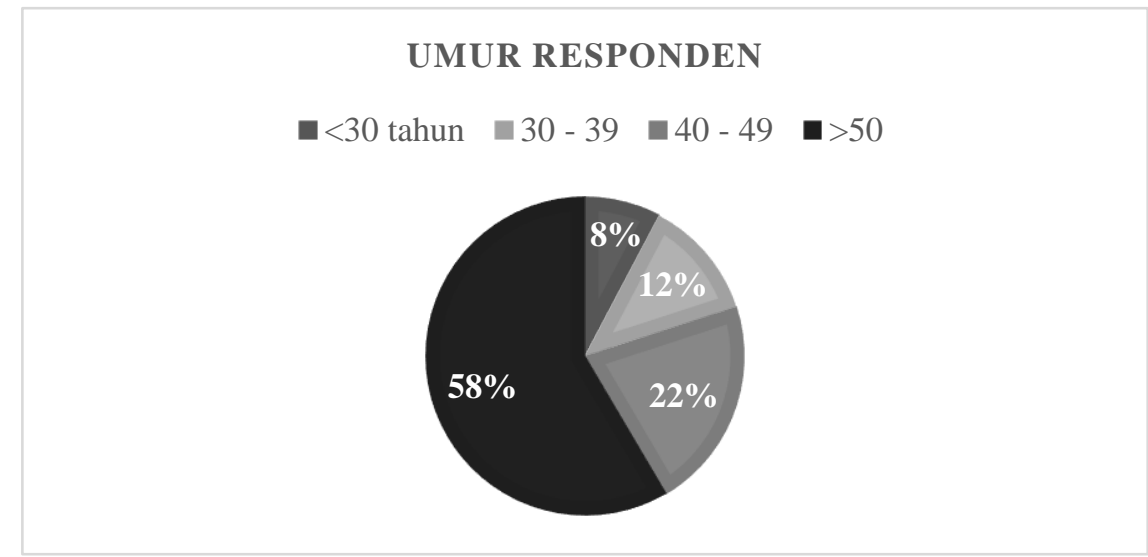

Gambar 2. Umur Pedagang di Pasar Kertosono

Sumber: Dokumen peneliti

Berdasarkan Gambar 2, diketahui bahwa mayoritas pedagang di Pasar Kertosono adalah pedagang dengan usia kerja yang masih produktif. Responden yang berasal dari Kelurahan Banaran, Kecamatan Kertosono, dan beberapa Kecamatan terdiri dari beberapa desa yang berbeda, dengan dikelompokan menjadi Banaran, Kertosono, dan Luar Kertosono. Pedagang terbanyak yaitu pedagang yang berasal dari Kelurahan Banaran yang berada di sekitar Pasar Kertosono dengan jumlah pedagang terbanyak yaitu mencapai 49,23\% yang merupakan lokasi keberadaan Pasar Kertosono lama maupun Pasar Kertosono baru.

TINGKAT PENDIDIKAN

- SMA $\quad$ SD dan SMP $\quad$ Perguruan Tinggi

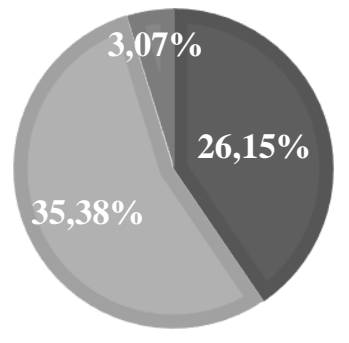

Gambar 3. Tingkat Pendidikan Pedagang di Pasar Kertosono

Sumber: Dokumen peneliti 
Berdasarkan hasil penelitianv (Gambar 3), diketahui bahwa mayoritas pendidikan pedagang di Pasar Kertosono adalah SD dan SMP, sedangkan tidak ada pedagang yang tidak tamat sekolah dasar. Ini berarti seluruh pedagang di Pasar Kertosono merupakan orang terdidik dan melek huruf.

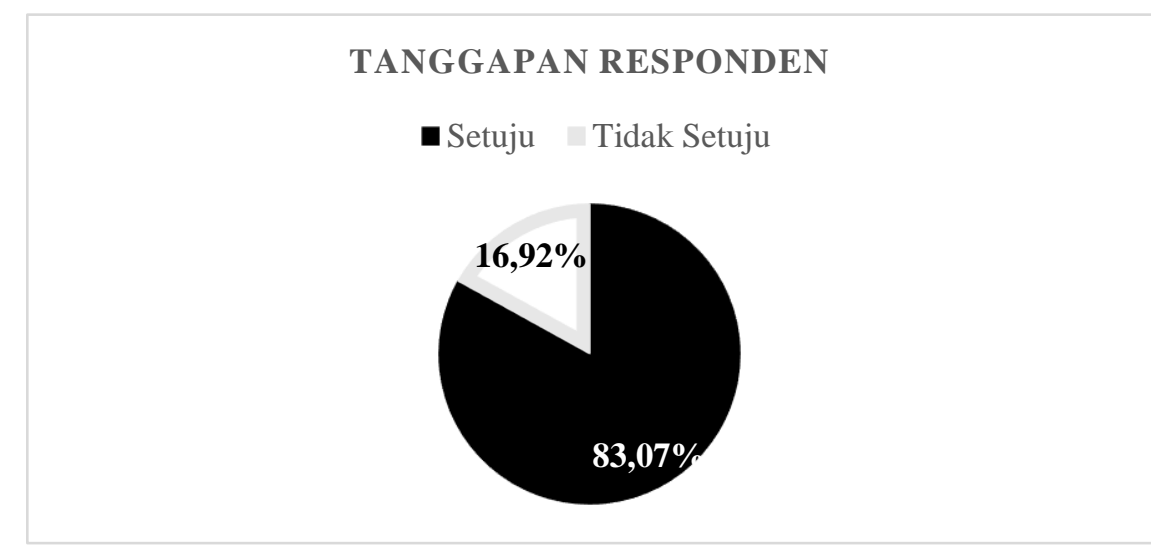

Gambar 4. Tanggapan Pedagang terhadap Relokasi di Pasar Kertosono

Sumber: Dokumen peneliti

Berdasarkan grafik di atas (Gambar 4), diketahui bahwa mayoritas responden tidak setuju dengan adanya relokasi pasar. Pedagang tidak menyetujui adanya relokasi pasar karena tempatnya kurang luas, penataan lapak kurang rapi, dan masih kurangnya lahan parkir, serta tempat yang kurang strategis. Ketidaksetujuan pedagang tersebut sejalan dengan Zunaidi (2013) yang menemukan bahwa pedagang menolak direlokasi karena kekhawatiran mahalnya harga lapak dan penurunan pendapatan. Akses jalan keluar masuk pasar kurang memadai menjadi salah satu alasan penolakan pedagang. Mengingat lahan yang digunakan relokasi pasar adalah lahan imigrasi dan lahan balai kelurahan. Hal tersebut selaras dengan hasil penelitian Manzanaris, Rares and Kiyai (2018) yang menyatakan bahwa sulitnya aksesibilitas ke pasar yang baru merugikan pedagang dan masyarakat sebagai konsumen. Sebanyak $16,92 \%$ responden menyatakan setuju terhadap kebijakan relokasi tersebut dengan alasan mengikuti peraturan dan tidak ada pilihan lain.

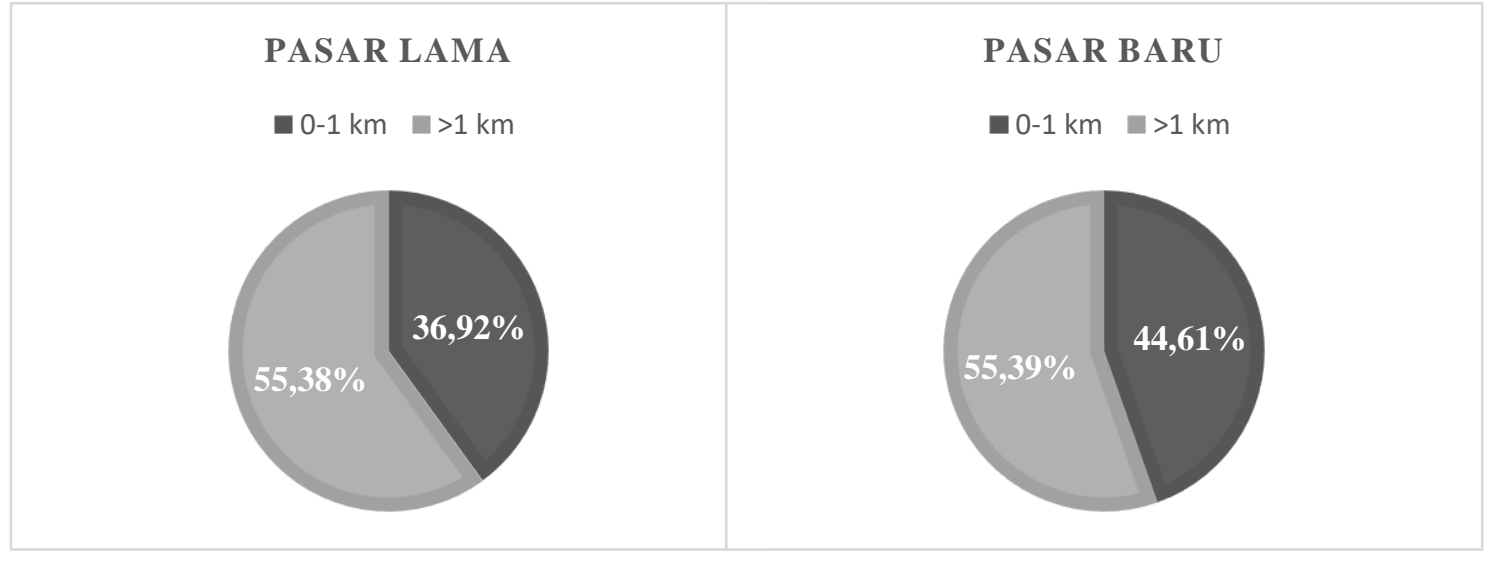

Gambar 5. Jarak Tempat Tinggal Pedagang dengan Pasar Kertosono

Sumber: Dokumen peneliti

Berdasarkan hasil penelitian, diketahui bahwa sebanyak 36,92\% responden rumahnya berjarak 0-1 $\mathrm{km}$ dengan Pasar Kertosono lama. Hal tersebut dikarenakan hampir dari setengah responden yang bertempat tinggal tidak jauh dari lokasi pasar lama. Setelah direlokasi sebanyak 44,62\% responden rumahnya berjarak 0-1 km dengan Pasar Kertosono baru. Hal tersebut dikarenakan lokasi Pasar Kertosono baru lebih dekat dari lokasi Pasar Kertosono lama. Semakin jauhnya lokasi Pasar Kertosono baru menyebabkan sebanyak 55,38\% responden harus menempuh jarak 1,1-2 km menuju Pasar Kertosono baru. 
Jarak rumah responden dari pasar lama dan baru tidak berubah secara signifikan. Hal tersebut dikarenakan jarak pasar lama ke lokasi pasar baru berdekatan dan berlokasi sama yang berada di Kelurahan Banaran, sehingga hanya terdapat perubahan jarak pada beberapa responden saja dari pasar lama ke pasar yang baru. Hal tersebut berbeda dengan hasil penelitian (Susilowati, 2015) yang menunjukkan bahwa paska relokasi pasar, biaya transortasi yang dikeluarkan semakin besar.

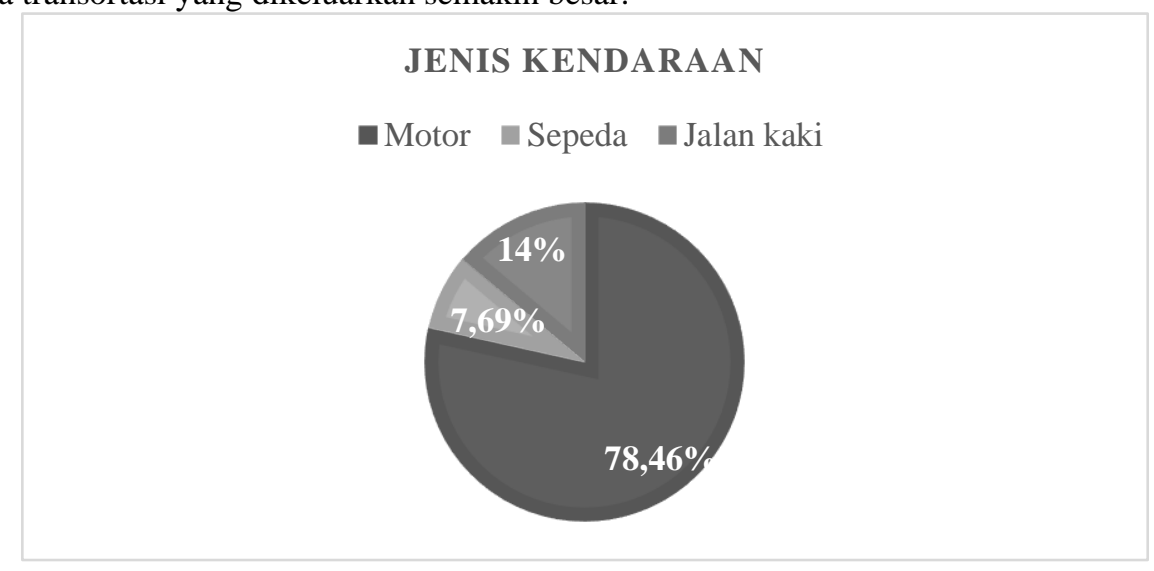

\section{Gambar 6. Jenis Kendaraan Pedagang di Pasar Kertosono \\ Sumber: Dokumen peneliti}

Berdasarkan data di atas (Gambar 6), dapat diketahui bahwa sebagian besar pedagang di Pasar Kertosono menggunakan sepeda motor sebagai alat transportasi menuju pasar. Setelah direlokasi terjadi perubahan jenis kendaran yang dipakai responden, dikarenakan pasar baru yang lebih dekat daripada pasar lama, maka responden lebih memilih jalan kaki dan bersepeda.

Pedagang mengeluarkan biaya transportasi untuk menuju Pasar Kertosono sebelum dan sesudah relokasi setiap harinya berbeda-beda. Mayoritas responden mengeluarkan biaya transportasi untuk menuju lokasi pasar, baik sebelum direlokasi maupun sesudah direlokasi. Namun, persentase responden yang mengeluarkan biaya transportasi pasca relokasi mengalami penurunan (Gambar 7) dikarenakan lokasi Pasar Kertosono baru yang semakin dekat dengan tempat tinggal para pedagang.

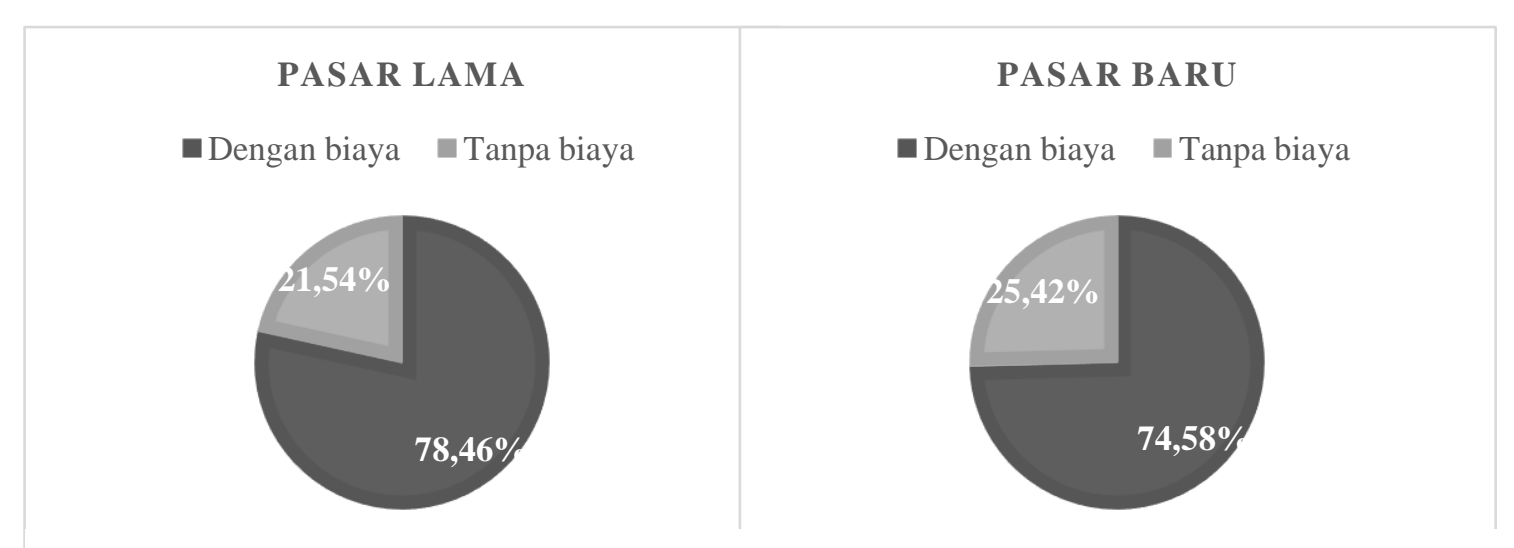

Gambar 7. Pedagang di Pasar Kertosono yang Mengeluarkan Biaya Transportasi.

Sumber: Dokumen peneliti

Peran pedagang dalam paguyuban di pasar lama dan pasar baru tidak jauh berbeda, hanya di pasar baru organisasi pedagang ditiadakan dikarenakan lokasi lapak yang masih belum tertata dengan rapi sehingga mempersulit untuk mengoordinir satu sama lain. Selaras dengan hasil penelitian Junaidi, Ramayanto and Nurlailatul (2018) yang menemukan bahwa belum adanya organisasi sosial pedagang paska relokasi karena interaksi yang kurang intens antar pedagang. Seberapa besar peran pedagang dalam paguyuban pasar tergantung dengan keaktifan dan posisi pedagang di dalam organisasi tersebut. 


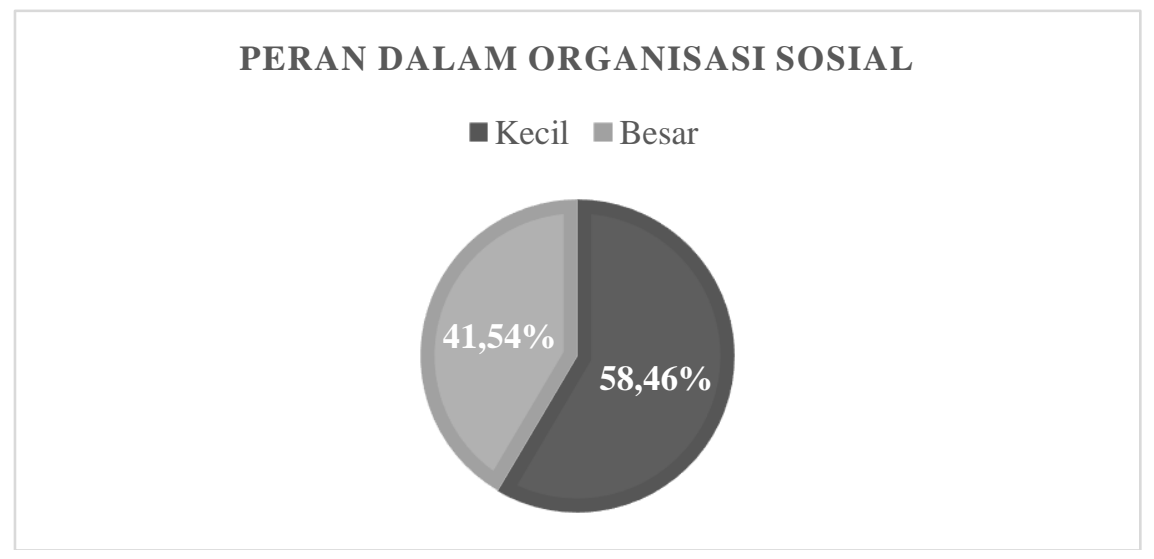

Gambar 8. Peran Pedagang dalam Organisasi Sosial di Pasar Kertosono Sumber: Dokumen peneliti

Berdasarkan data di atas (Gambar 8), diketahui bahwa di pasar lama, mayoritas pedagang memiliki peran yang kecil, artinya pedagang tidak terlibat aktif dan hanya menjadi anggota organisasi pasif dengan alasan malas dan waktu kerja sudah cukup menguras tenaga dan waktu. Sedangkan 41,54\% pedagang memiliki peran yang besar karena responden sadar akan adanya organisasi pedagang di Pasar Kertosono dan menduduki jabatan yang penting dalam organisasi. Mereka merelakan waktu dan tenaganya lebih banyak demi kemajuan dan kerukunan bersama antar sesama pedagang.

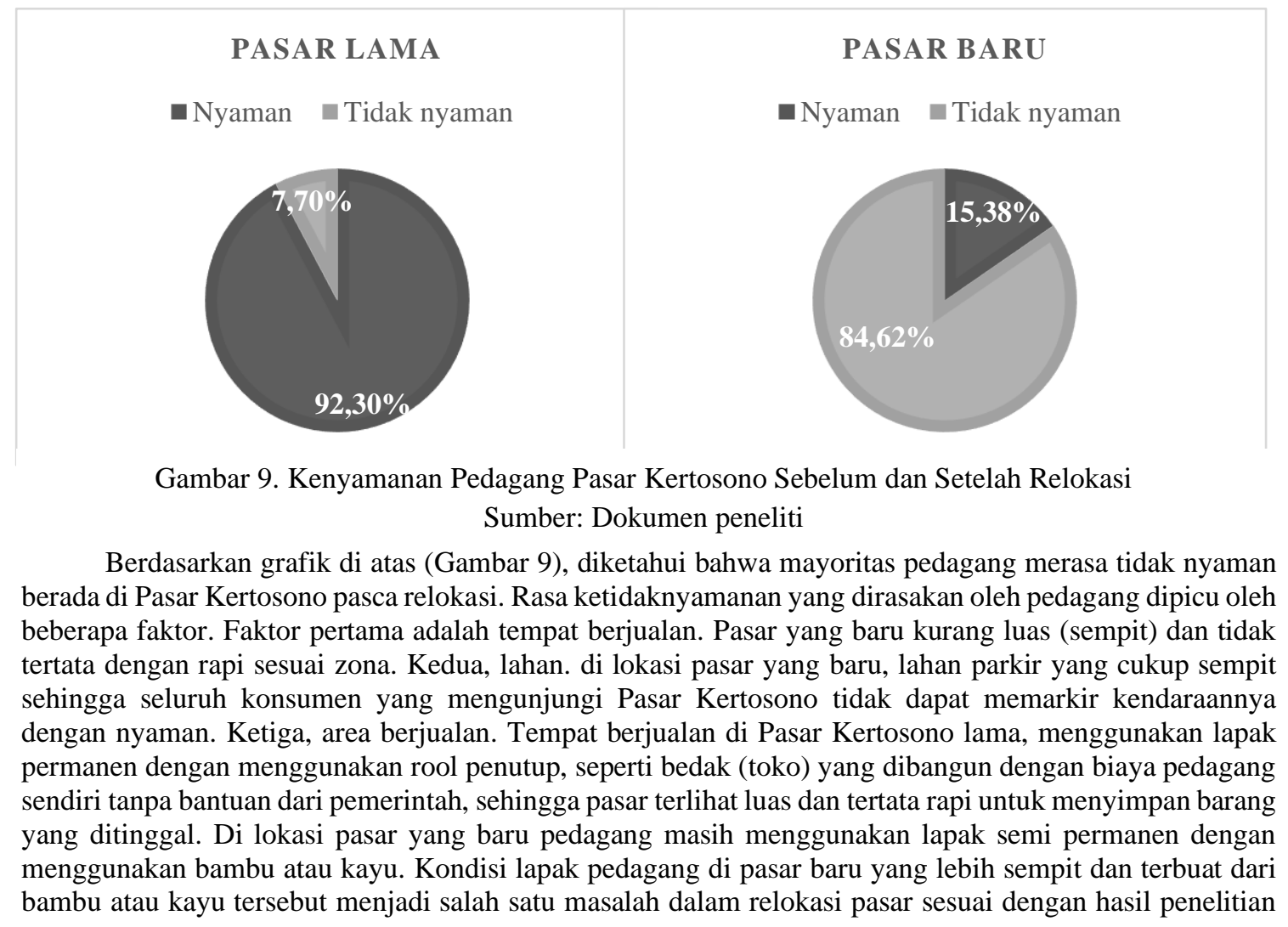


(Fauzi and Firdaus, 2019) yang menyatakan bahwa bangunan pasar baru tidak sesuai dengan ekspektasi pedagang sehingga menimbulkan protes dari pedagang pasar. Di pasar baru lokasinya kurang tertata dengan baik sesuai zona seperti di pasar lama, sehingga pedagang kehilangan pelanggan tetapnya. Dilakukannya relokasi Pasar Kertosono juga disayangkan oleh banyak pedagang karena kenyamanan yang berlawanan dengan pendapatan yang diperoleh pedagang, karena pendapatan yang semakin menurun dibandingkan sebelum terjadinya relokasi. Sejalan dengan Endrawanti and Wahyuningsih (2014) yang menyatakan bahwa pasar modern paska relokasi terlihat lebih bersih, aman, dan nyaman namun tidak diikuti dengan kenaikan pendapatan yang signifikan. Hal ini menunjukkan salah satu dampak negatif relokasi pasar bagi pedagang, sebagaimana Safitri (2020) yang menemukan bahwa pasar menjadi sepi pembeli pasca dilakukannya relokasi.

Pedagang merasa lebih nyaman di pasar lama sebelum relokasi disebabkan oleh beberapa faktor. Luasnya lokasi pasar merupakan faktor utama karena banyaknya pembeli dan lapak pedagang yang tertata dengan rapi sesuai zona-zona yang ditentukkan. Lokasinya yang sangat luas dengan akses jalan yang baik untuk pengunjung atau pembeli maupun pedagang yang menuju pasar. Di pasar lama, ketersediaan lahan parkir luas, sehingga banyak calon konsumen yang datang untuk berbelanja di sana. Di pasar lama, pedagang juga menyatakan nyaman saat berjualan karena mereka sudah memiliki pelanggan tetap ketika berjualan lama di sana.

Selain rasa nyaman yang dirasakan pedagang saat berdagang, masalah lain berkaitan dengan relokasi pasar berhubungan dengan keamanan, kebersihan, keterbatasan lahan parkir, lapak yang sempit, dan lain sebagainya. Sebelum relokasi, sebanyak 92,30\% responden tidak menjumpai permasalahan yang berhubungan dengan kegiatan berdagang. Biasanya, masalah yang muncul di pasar lama yaitu masalah lingkungan pasar yang kotor. Tetapi, hal tersebut tidak menjadi permasalahan utama. Permasalahan besar yang dijumpai pedagang sebelum relokasi yaitu banyak pedagang yang kehilangan barang dagangan yang tidak dapat diselamatkan dari kebakaran pasar lama tersebut. Hal tersebut tidak diharapkan oleh semua pedagang, yang sebelum adanya kebakaran aktivitas dalam pasar aman dan berjalan dengan lancar. Intinya, selama berdagang di pasar lama, pedagang hanya menjumpai permasalahan kecil yang dapat langsung diselesaikan (Gambar 10).

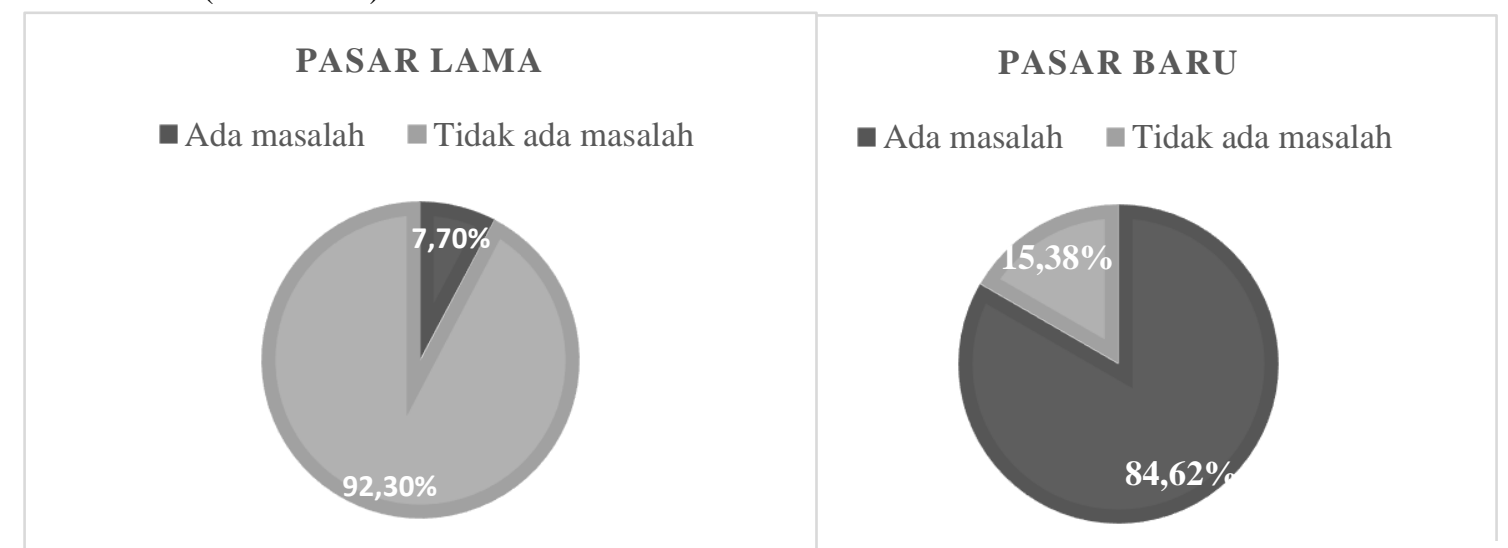

Gambar 10. Permasalahan dalam berdagang di Pasar Kertosono Sebelum dan Setelah Relokasi Sumber: Dokumen peneliti

Berdasarkan grafik di atas (Gambar 10) diketahui bahwa sesudah terjadinya relokasi, sebanyak $84,61 \%$ responden menjumpai masalah yang berarti selama berjualan, artinya terjadi peningkatan permasalahan yang dihadapi pedagang sebesar 76,94\%. Permasalahan yang biasanya muncul di pasar baru yaitu: kenyamanan pedagang, sempitnya lokasi pasar dan terbatasnya lahan parkir, menjadikan pedagang dan konsumen kurang nyaman saat beraktivitas jual beli, dan sebagainya. Pada kenyataannya setelah masalah tersebut teratasi muncul permasalahan baru yang dihadapi pedagang, salah satunya menurunnya pendapatan pedagang setelah direlokasi ke lokasi pasar yang baru. Banyak bermunculan pedagangpedagang menjadi salah satu keluhan yang menyebabkan menurunnya pendapatan pedagang dikarenakan akses jalan menuju ke pasar baru sempit, maka pelanggan mengurungkan niatnya yang hendak pergi pasar. Jumlah pembeli yang relatif tetap tidak sebanding dengan luas pasar baru yang lebih kecil dari luas pasar lama. 


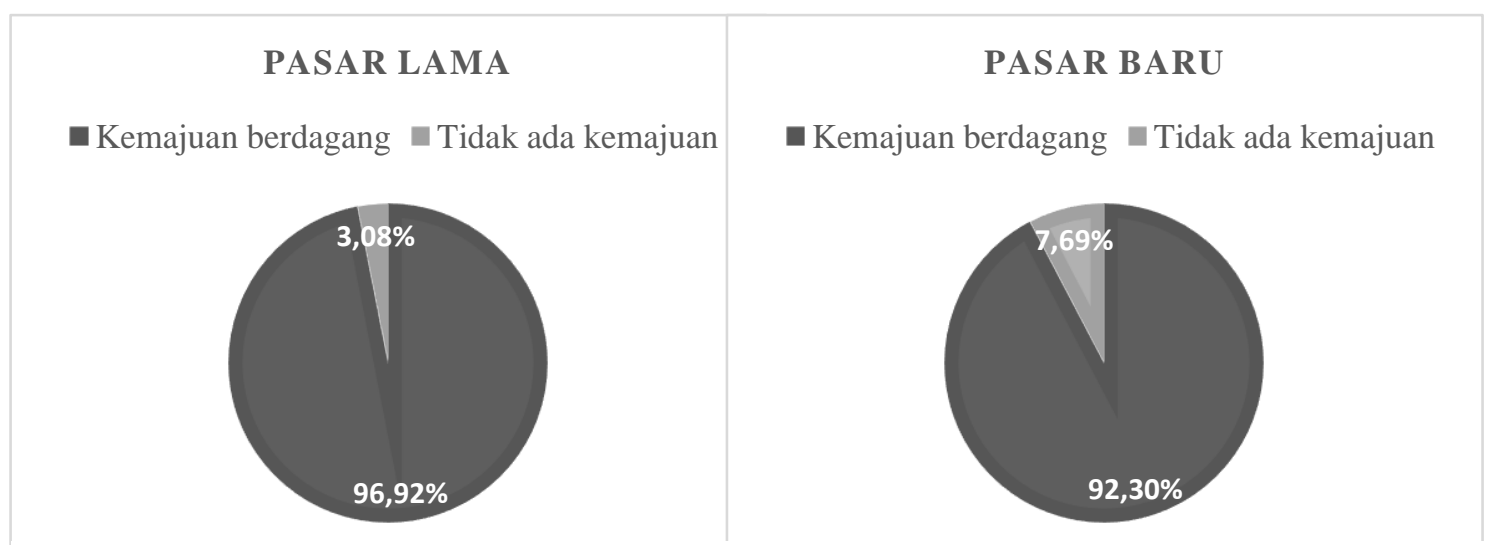

Gambar 11. Kepastian Usaha di Pasar Kertosono Sebelum dan Setelah Relokasi

Sumber: Dokumen peneliti

Berdasarkan grafik di atas (Gambar 11), diketahui bahwa sebelum direlokasi sebanyak 96,92\% responden menyatakan dapat maju sewaktu berjualan, sisanya menyatakan tidak dapat maju. Sebagian besar responden merasa usaha dagangnya dapat berkembang karena telah mempunyai pelanggan tetap. Sesudah direlokasi, jumlah responden yang menyatakan dapat maju sewaktu berjualan terjadi penurunan sebesar 4,62\%. Responden menyatakan tidak dapat maju sewaktu berjualan karena kehilangan pelanggan tetap. Banyak pelanggan yang berpindah ke pedagang lain. Akan tetapi mayoritas pedagang yang menyatakan usahanya akan lebih maju, jika pemerintah bisa lebih memperhatikan dan membangun kondisi pasar menjadi lebih baik sehingga dapat memberikan rasa nyaman bagi pedagang, walaupun kemajuan yang dirasakan sedikit demi sedikit, membutuhkan waktu dan adaptasi yang cukup lama.

Hasil interview juga menunjukkan bahwa di Pasar Kertosono yang lama para pedagang diwajibkan membayar biaya retribusi sebesar Rp500,- sampai dengan Rp2.000,- setiap harinya oleh pemerintah daerah setempat atau petugas pasar yang berwewenang, sesuai luas lapak masing- masing pedagang. Setelah terjadinya relokasi ke lokasi Pasar Kertosono yang baru, pemerintah daerah setempat memutuskan tidak akan memungut biaya retribusi setiap harinya yang harus dibayar oleh pedagang, akan tetapi petugas pasar memungut biaya retribusi untuk listrik sebesar Rp50.000,- setiap bulan. Pemungutan retribusi listrik tidak dilakukan secara langsung paska relokasi. Dinas Pengelolaan Pasar melakukan pendampingan dan memberikan waktu kepada pedagang untuk beradaptasi dengan lokasi Pasar Kertosono baru.

Modal yang dikeluarkan pedagang banyak berubah. Banyak pedagang yang bermodalkan lebih sedikit daripada saat sebelum direlokasi, ini disebabkan karena pedagang takut apabila modalnya ditambah tetapi jumlah pembeli tetap atau sedikit, maka mereka akan merugi. Apalagi pedagang takut jika kehilangan pelanggan tetap, dikarenakan pelanggan juga harus mencari lagi pedagang langganannya. Selain itu, tidak semua pedagang bisa membawa dagangan ke pasar baru akibat kebakaran. Pasca relokasi, hampir semua pedagang membutuhkan modal operasional senilai \pm Rp20.000.000,00. Padahal, sebelum direlokasi, modal operasional yang dikeluarkan pedagang sangat besar yakni mencapai \pm Rp35.000.000,00 hingga \pm Rp60.000.000,00. Menurunnya modal operasional yang dikeluarkan pedagang karena sebagian besar modalnya bersumber dari pinjaman bank, sebab sebagian barang dagangan pedagang hangus terbakar. Hal serupa terjadi di Pasar Induk Wua-Wua Kota Kendara dimana pedagang pasar direlokasi akibat terjadinya kebakaran sehingga berdampak pada modal usaha pedagang yang menurun (Asiah, Moita and Supiyah, 2020).

Besar pendapatan yang diperoleh responden di Pasar Kertosono sebelum maupun sesudah relokasi dalam waktu satu bulan mengalami perubahan. Sebelum relokasi sebanyak 15,38\% responden memiliki pendapatan sangat rendah, akan tetapi sesudah direlokasi responden dengan pendapatan yang sama meningkat sebesar $66,15 \%$. Sebelum relokasi, sebanyak $84,61 \%$ responden memiliki pendapatan sangat tinggi dan sesudah relokasi terjadi penurunan pada pendapatan sebesar $50,77 \%$. Secara umum, terjadi penurunan pendapatan yang diperoleh responden setelah direlokasi. Rata-rata pendapatan pedagang sebelum direlokasi mencapai Rp15.000.000,00 - Rp40.000.000,00, sedangkan di pasar baru sebesar Rp5.000.000,00 hingga $<$ Rp10.000.000,00. Salah satu penyebab menurunnya pendapatan pedagang karena berpindahnya lokasi dagang yang berbeda dengan sebelumnya sehingga pelanggan lama kesulitan untuk 
menemukan lokasi pedagang yang baru. Hal tersebut sesuai dengan penelitian Armi et al. (2016) yang menemukan bahwa konfigurasi kios pedagang yang berbeda dari sebelumnya. Semakin membaiknya kondisi pasar saat ini belum mampu meningkatkan hasil pendapatan pedagang. Kenyamanan yang dirasakan beberapa pedagang di pasar yang baru juga belum sebanding dengan pendapatan yang mereka peroleh. Pedagang-pedagang lama banyak yang kehilangan pelanggan sehingga berdampak pada pendapatan mereka. Pedagang menawarkan harga serendah mungkin dengan keuntungan yang kecil demi mendapatkan pembeli supaya barang dagangan yang mereka jajakan dapat laku terjual.

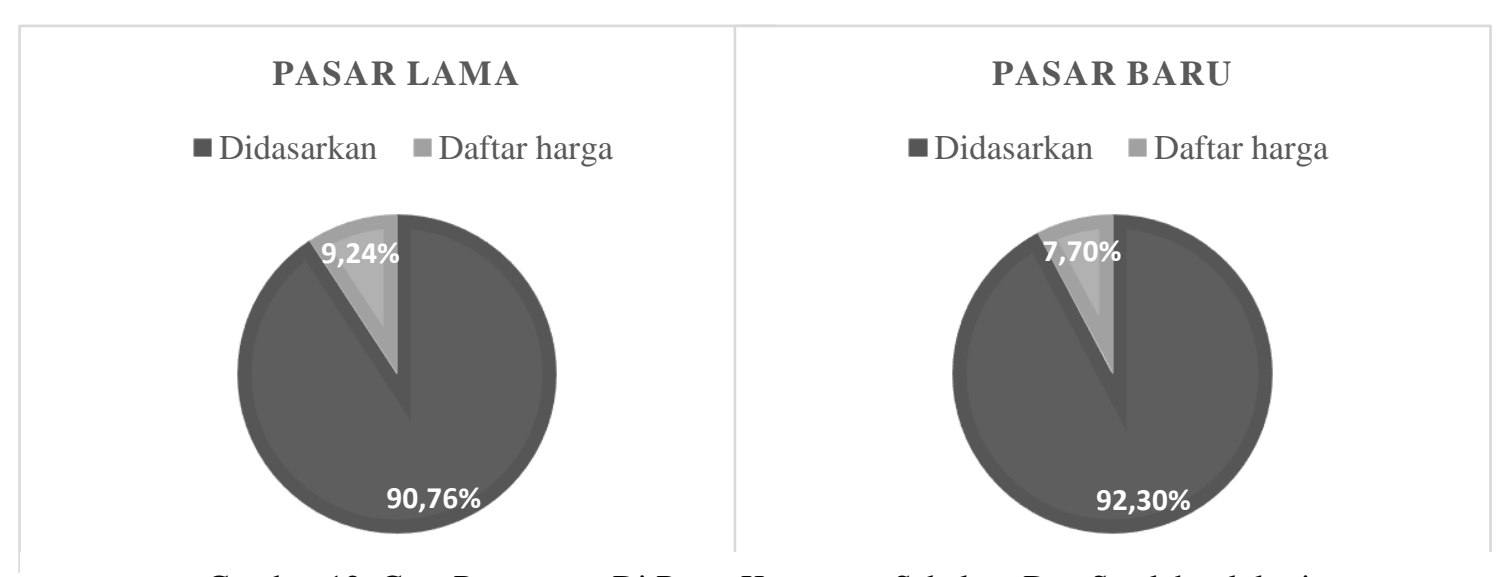

Gambar 12. Cara Pemasaran Di Pasar Kertosono Sebelum Dan Setelah relokasi

Sumber: Dokumen peneliti

Sebelum relokasi pasar, sebanyak 90,76\% responden memasarkan barang dagangannya dengan cara didasarkan pada lapak dan ditawarkan kepada pembeli secara lisan, sisanya memasarkan barang dagangannya dengan cara membuat daftar harga. Sedangkan sesudah terjadinya relokasi pasar sebanyak 92,30\% responden memasarkan barang dagangannya dengan cara didasarkan di lapak dan menawarkan pada pembeli secara lisan, sisanya memasarkan barang dagangannya dengan cara membuat daftar harga. Berdasarkan hasil penelitian tersebut terjadi peningkatan sebesar $0,98 \%$ cara pemasaran dengan didasarkan pada lapak dan menawarkan secara lisan, sementara itu terjadi penurunan sebesar 1,20\% cara pemasaran dengan membuat daftar harga. Sebagian besar pedagang masih mempertahankan cara pemasaran dari sebelum terjadinya relokasi yang dianggap lebih mudah dan efektif, tetapi ada beberapa pedagang yang merubah cara pemasarannya yang dipengaruhi karena tempat berjualan mereka yang memungkinkan untuk merubah cara pemasarannya dengan tujuan memperoleh pendapatan yang lebih baik.

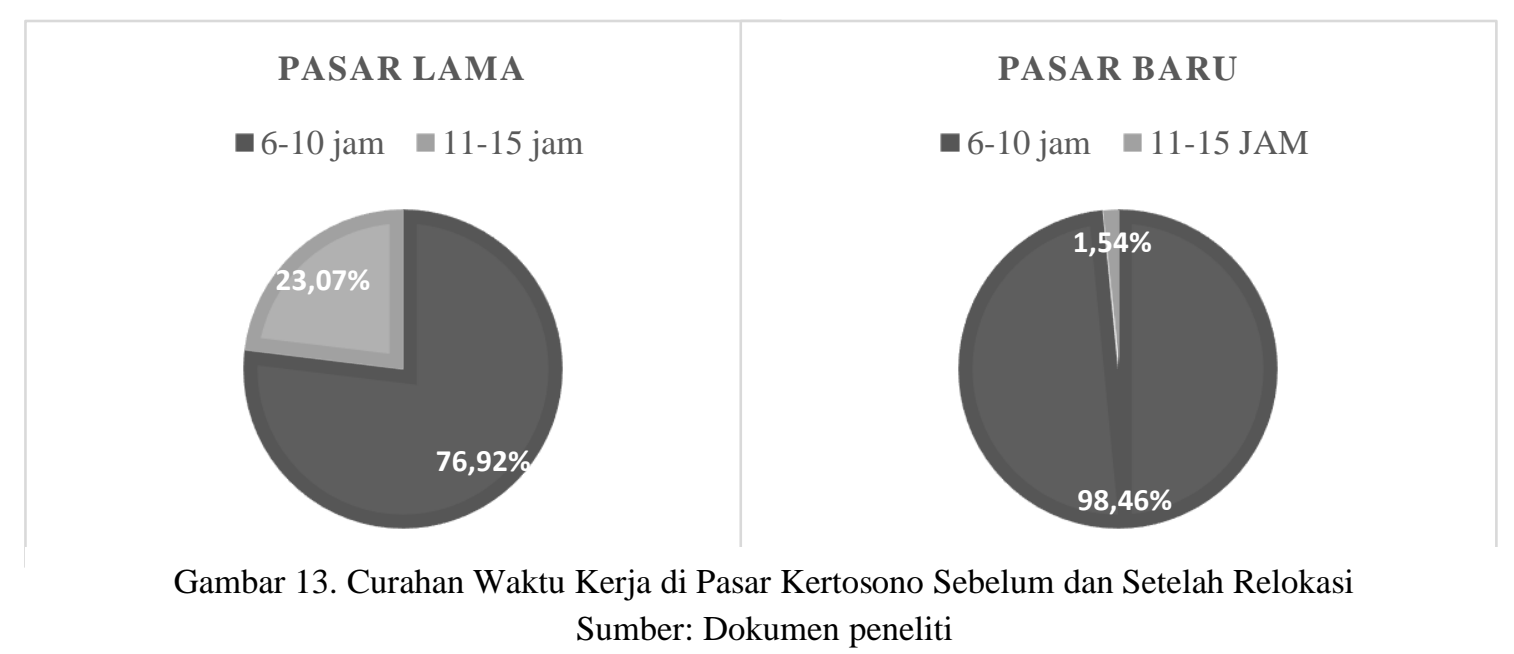

Setelah menempati Pasar Kertosono yang baru jam kerja 6-10 jam per hari semakin meningkat sebesar 21,54\%, dan jam kerja 11-15 jam menurun sebesar 21,54\%. Hal ini dikarenakan barang dagangan yang seharusnya sudah habis terjual pada saat menempati lokasi lama ternyata masih tersisa setelah 
direlokasi ke lokasi yang baru dan barang dagangan yang seharusnya ditinggal di lapak (bedak toko) menjadi dibawa pulang setelah relokasi pasar yang hampir semuanya belum membuat lapak permanen, sehingga memaksa pedagang untuk mengurangi jam kerjanya agar dapat berberes lebih awal. Penurunan jam operasional pedagang tersebut sejalan dengan hasilpenelitian (Soelistiyono, Adrianto and Kuniawati, 2018) yang menunjukkan bahwa setelah diadakannya relokasi pasar, jam operasional pasar berkurang dan jam operasional pasar juga telah diatur. Jam kerja antara 11-15 jam per hari biasanya dilakukan oleh pedagang yang sudah membuat lapak permanen dan menjual barang yang tidak langsung habis terpakai, seperti pakaian jadi, kain, alat pertanian, dan sebagainya.

\section{KESIMPULAN}

Hasil penelitian dan pembahasan di atas, dapat diambil kesimpulan bahwa mayoritas responden tidak setuju terhadap adanya relokasi Pasar Kertosono disebabkan pasar baru memiliki lahan yang sempit, akses jalan dan lahan parkir yang tidak memadai. Aksesibilitas menuju Pasar Kertosono baru lebih dekat dengan rumah pedagang di mana pedagang yang tempat tinggalnya berjarak 0-1 km meningkat sebesar $7,69 \%$, sehingga mudah dijangkau dengan berjalan kaki, sepeda, dan sepeda motor. Relokasi Pasar Kertosono berdampak pada kondisi sosial pedagang yaitu hilangnya organisasi sosial di pasar lama, kenyamanan dalam berdagang meningkat $7,69 \%$, dan pedagang yang mengalami permasalahan dalam berdagang meningkat mencapai $86,16 \%$. Sedangkan, relokasi Pasar Kertosono berdampak terhadap kondisi ekonomi pedagang yaitu tidak dipungutnya retribusi lapak dan hanya membayar retribusi listrik sebesar Rp50.000,00/bulan, modal operasional yang dikeluarkan menjadi lebih kecil, pendapatan pedagang menurun, dan curahan waktu kerja pedagang menurun.

\section{SARAN}

yang dapat diberikan yaitu dibutuhkan bantuan modal khususnya bagi pedagang kecil yang ada di Pasar Kertosono. Dimana pedagang ini tidak bisa melakukan ekspansi usaha karena keuntungan yang didapatkan tidak besar. Selain itu hasil dari berdagang hanya cukup untuk memenuhi kebutuhan seharihari. Selain itu diperlukan pula sharing knowledge mengenai perencanaan keuangan agar para pedagang dapat membedakan mana uang yang harus dikelola untuk berdagang dan mana uang yang harus digunakan untuk kebutuhan sehari-hari. Serta di era digital ini, pedagang di pasar kertosono juga perlu diajarkan pemasaran digital agar usaha dapat terus berjalan meskipun di masa pandemik Covid-19.

\section{DAFTAR PUSTAKA}

Aliyah, I., Setioko, B. and Wisnu, P. (2015) 'Eksistensi Pasar Tradisional dalam Kearifan Budaya Jawa (Obyek Studi: Pasar Gede Kota Surakarta)', SEMINAR NASIONAL: Menuju Ruang Arsitektur \& Perkotaan Yang Ber-Kearifan Lokal.

Armi, A. et al. (2016) 'Dampak Sosial Ekonomi Relokasi Pasar', Jurnal Administrasi Publik.

Ars (2015) Peran Pasar Tradisional Sebagai Pondasi Dasar Ekonomi Kerakyatan, 17.05.2015.

Asiah, N., Moita, S. and Supiyah, R. (2020) 'The Socio-Economic Impacts After Relocation of Pasar Panjang Traders to the Wua-Wua Central Market Kendari City', Indonesian Journal of Social and Environmental Issues, 1(1). Available at: https://ojs.literacyinstitute.org/index.php/ijsei.

Endrawanti, S. and Wahyuningsih, C. D. (2014) 'Dampak Relokasi Pasar Studi Kasus di Pasar Sampangan Kota Semarang', Serat Acitya-Jurnal Ilmiah UNTAG Semarang, 3(1).

Fauzi, H. M. and Firdaus, A. Y. (2019) 'Impacts of Traditional Market Revitalization on the Traders' Capital Expenditure in Situbondo', in The International Seminar Series of Regional Dynamics Proceeding.

Hasnawati (2016) Dampak Relokasi Pasar Terhadap Kondisi Sosial Ekonomi Pedagang Pasar Laino Raha. Universitas Halu Oleo Kendari.

Izza, N. (2010) Pengaruh Pasar Modern terhadap Pedagang Pasar Tradisional (Studi Pengaruh Ambarukmo Plaza terhadap Perekonomian Pedagang Pasar Desa Caturtunggal Nologaten Depok Sleman Yogyakarta). UIN Sunan Kalijaga Yogyakarta.

Junaidi, M., Ramayanto and Nurlailatul (2018) 'Dampak Relokasi Pasar terhadap Kondisi Sosial Ekonomi Pedagang Pasar Tente Kecamatan Woha Kabupaten Bima’, Jurnal Ilmu Administrasi Publik, 6(1). doi: DOI: https://doi.org/10.31764/jiap.v6i1.659.

Koentjaraningrat (1981) Pengantar Antropologi. Jakarta: Rineka Cipta.

Losch, A. (1954) Economic of Location. New York: John Wiley \& Sons, Inc. 
Manzanaris, M. R., Rares, J. and Kiyai, B. (2018) 'DAMPAK KEBIJAKAN RELOKASI PASAR TRADISIONAL RAWAJAYA DI WILAYAH KOTA TOBELO KABUPATEN HALMAHERA UTARA', JURNAL ADMINISTRASI PUBLIK, 4(52).

Masitoh, E. Al (2013) 'Upaya Menjaga Eksistensi Pasar Tradisional: Studi Revitalisasi Pasar Piyungan Bantul', Jurnal PMI.

Muslimin, L., Indriati, F. and Widayanti, T. (2018) 'KAJIAN MODEL PENGEMBANGAN PASAR TRADISIONAL', Buletin Ilmiah Litbang Perdagangan. doi: 10.30908/bilp.v1i2.296.

Musthofa, Z. (2011) Evaluasi Pelaksanaan Program Relokasi Permukiman Kumuh (Studi Kasus Kelurahan Pucangsawit, Kota Surakarta). Universitas Sebelas Maret.

Muta'ali, L. (2015) Teknik Analisis Regional untuk Perecanaan Wilayah Tata Ruang dan Lingkungan. Yogyakarta: Badan Penerbit Fakultas Geografi.

Nurjanah, N. (2020) 'Selamatkan Pasar Tradisional', Umbara. doi: 10.24198/umbara.v3i2.29639.

Pramudyo, A. (2014) 'Menjaga eksistensi pasar tradisional di yogyakarta', Jbma.

Safitri, D. (2020) Analisis Dampak Relokasi Pasar Tradisional Terhadap Pendapatan Pedagang Sebelum dan Sesudah Relokasi (Studi di PasarA ngso Duo). Universitas islam Negeri Sulthan Thaha Saifuddin.

Sari, R. K. (2006) 'Sistem Penentuan Daerah Relokasi Pemukiman Masyarakat di Kota Banda Aceh Berbasis Sistem Informasi Geografis', Jurnal Fakultas Teknologi Industri Jurusan Teknik Informatika Universitas Gunadarma.

Soelistiyono, A., Adrianto, A. T. and Kuniawati, E. (2018) 'Analyzing the Impact of Traditional Market Relocation in Surrounding Traders amd Communities (Case studi of Demak Mranggen Marker', Economics and Business Solutions Journal, 2(1).

Susilowati, S. (2015) 'The Impact of Traditional Market Relocation on the Seller Dinoyo Market in Malang', Jurnal Vokasindo, 3(1).

Susilowati, S. H. (2014) 'Attracting the Young Generation to Engage in Agriculture', FFTC-RDA International Seminar on Enhanced Entry of Young Generation into Farming.

Susilowati, S. H. (2016) 'Fenomena Penuaan Petani dan Berkurangnya Tenaga Kerja Muda serta Implikasinya bagi Kebijakan Pembangunan Pertanian', Forum penelitian Agro Ekonomi. doi: 10.21082/fae.v34n1.2016.35-55.

Tarigan, R. (2006) Ekonomi Regional: Teori dan Aplikasi (Edisi Revisi). Jakarta: Bumi Aksara.

Widodo, E. (2008) Perancangan Kembali Pasar Tanjung Kota Mojokerto. Universitas Brawijaya.

Wiryomartono, B. P. (1995) Seni Bangunan dan Senin Binakota di Indonesia. Jakarta: Gramedia Pustaka Utama.

Yudha, M. R. A. (2017) Analisis Kondisi Sosial Ekonomi Pedagang Sebelum dan Sesudah Relokasi (Studi Kasus di Pasar SMEAP Tanjung Karang, Kota Bandar Lampung). Universitas Lampung.

Zunaidi, M. (2013) 'Kehidupan Sosial Ekonomi Pedagang Di Pasar Tradisional Pasca Relokasi Dan Pembangunan Pasar Modern', Jurnal Sosiologi Islam. 